\title{
EDITORIAL
}

\section{Congresso de Psicologia Escolar e Educacional: espaço para compartilhar.}

A Associação Brasileira de Psicologia Escolar e Educacional - a ABRAPEE - está mobilizada com a organização do VII Congresso Nacional de Psicologia Escolar e Educacional - CONPE. Seu objetivo é possibilitar a apresentação das mais recentes produções científicas da área e viabilizar um espaço para discussões, congregando profissionais e estudantes. Ocorrerá em Curitiba/ PR, na Universidade Tuiuti, de 21 a 24 de abril de 2005. Contamos com a participação não somente de profissionais e estudantes de Psicologia, mas também com a de todos aqueles comprometidos com uma educação brasileira de qualidade.

Psicologia Escolar e Educacional: da teoria à prática escolar é uma temática que sinaliza para uma reflexão acerca da pesquisa científica e atuação profissional sob diferentes perspectivas, que demonstrem seu compromisso com as atuais necessidades da educação brasileira. As conferências, mesas-redondas, painéis e relatos de experiências revelarão o atual panorama da Psicologia Escolar e Educacional no Brasil. Acrescentese a essas atividades, os minicursos que possibilitarão uma atualização tanto aos profissionais quanto aos estudantes, visto que estarão apresentando e discutindo os mais relevantes e diversificados temas psicoeducacionais.

Considerando-se a importância das informações a serem compartilhadas no VII CONPEe a necessidade de garantir-lhes um registro mais detalhado e permanente, fica aqui explicitado o convite desse periódico para a publicação de artigos científicos e relatos de experiências, organizados com base nas apresentações do Congresso. Pretendemos, assim, ampliar e aprofundar o espaço de interlocução entre nossos pares, até mesmo com aqueles que não puderem participar do referido evento. É importante destacar que a distribuição da revista é feita aos sócios da ABRAPEE, bibliotecas de todos os cursos de Psicologia do país, Conselho Federal de Psicologia, Conselhos Regionais de Psicologia, Sociedades científicas brasileiras e estrangeiras e Fundações ligadas à área. É enviada também para bibliotecas de Universidades estrangeiras, com as quais mantém intercâmbio, e realizada permuta com outros periódicos brasileiros.

Nesse sentido, queremos compartilhar com os leitores da Psicologia Escolar e Educacional que temos recebido muitos manuscritos com relato de pesquisas e experiências de todas as regiões brasileiras. Isso revela, por um lado, que temos muitos profissionais investigando e atuando na área, e, por outro, que esse periódico tem sido reconhecido e se consolidado como um meio de divulgação científica da área, o que é de fato seu objetivo primeiro.

Visando ampliar a abrangência da revista e possibilitar um acesso mais ágil e dinâmico por pesquisadores, tanto brasileiros quanto estrangeiros, favorecendo ainda mais a disseminação da produção científica brasileira na área e o intercâmbio entre pares e pessoas interessadas na Psicologia Escolar e Educacional, a revista está se organizando tecnicamente para ser editada também eletronicamente. Esta é uma meta a ser atingida em 2005. 
Esperamos que as contribuições presentes nesse número, por seu caráter inédito e por instigarem à reflexão e a uma prática comprometida com a ciência psicológica, possam ser de interesse de todos os leitores. Procurando facilitar eincentivar a interlocução entre os pares estamos disponibilizando, a partir desse fascículo, endereço postal e eletrônico dos autores de cada artigo.

Maria Cristina Rodrigues Azevedo Joly

Editora 